\title{
SCHEDULING PRACTICAL GENERATING SYSTEM USING AN IMPROVED BACTERIAL SWARM OPTIMIZATION
}

\author{
Raviprabakaran Vijay, C. Subramanian Ravichandran
}

Original scientific paper

This paper offers an improved technique namely, Quorum sensing based Bacterial Swarm Optimization (QBSO) technique to solve Practical Dynamic Economic Dispatch (PDED) problem. Quorum sensing is the communication signalling mechanism that permits the bacteria to organize the collective behaviour. The enhanced QBSO method improves the exploration capability of bacterial swarm. The practicability of the proposed method is tested on standard 10 generating unit system and the public practical south Indian 20 thermal generating system with recorded load demand profiles. The enhanced technique increases the operational speed of scheduling and reduces the generating cost of standard system and the thermal generating units owned by Tamilnadu Generation and Distribution Corporation Limited (TANGEDCO). The presented technique outperforms when compared with conventional bacterial swarm optimization technique and some recently published methods.

Keywords: Dynamic Economic Dispatch; Practical Load Demand Profiles; Quorum Sensing based Bacterial Swarm Optimization; 20 South Indian Thermal Units

Programiranje praktičnog sustava generiranja uporabom poboljšane optimizacije bakterijskog roja

Izvorni znanstveni članak Ovaj rad nudi poboljšanu metodu, naime, Quorum sensingbased Bacterial Swarm Optimization (QBSO) metodu za rješavanje problema praktične dinamične ekonomične isporuke - Practical Dynamic Economic Dispatch (PDED). Prepoznavanje kvoruma je mehanizam za signaliziranje komunikacije koji omogućuje organiziranje kolektivnog ponašanja bakterija. Poboljšana QBSO metoda povećava istraživačku sposobnost roja bakterija. Praktičnost predložene metode ispitana je na standardnomsustavu od 10 jedinicageneriranja energije i javnom praktičnom južno indijskom sustavu od 20 jedinica za generiranjetoplinske energije sa snimljenim profilima potrebnogopterećenja. Ta poboljšana metoda povećava operativnu brzinu programiranjaoperacija smanjuje troškove generiranja standardnog sustava i jedinicaza dobivanje toplinske energije u vlasništvu Tamilnadu Generation and Distribution Corporation Limited (TANGEDCO). Prikazana metodaje bolja u usporedbi s konvencionalnom metodom optimizacije roja bakterija inekim nedavno objavljenim metodama.

Ključne riječi: dinamična ekonomična isporuka; 20 South Indian Thermal Units; optimizacija roja bakterija temeljena naprepoznavanju kvoruma; praktični profili potreba opteréenja

\section{Introduction}

The Dynamic Economic Dispatch (DED) is one of the vivacious practical optimization problems in power system [1]. It targets the most impartial schedule of the committed online generating units for each horizon to satisfy the load demands. Power generation companies (Gencos) are anticipated to save the generation cost with satisfying practical generation operating limits. In the competitive power market, the existence of precise and quick scheduling of thermal generating units can reduce the generation cost substantially. The minimum cost of generation reduces the customer's electricity tariff. In the meantime, the optimal allocation of units maintains the reliability and decreases the load shedding of the electrical power system. Generally, the strain in the generator rotor is within certain limits. This ramp rate limit will reduce the power output and lifespan of generators [2]. In the real-world problems, the accurate scheduling of the system is accomplished by inclusion of valve point loading effects. The other complex limitations include the thermal generated power that should satisfy the power demand and transmission losses [3]. Correspondingly, the faults in the steam boiler feed pumps causes the vibrations in the generators shaft. During this period the generating units have to operate within these vibration zones. For efficient operation these units have to prohibit these zones [4]. Hence the PDED problem is accepted as multifaceted practical optimization problems in power system.
Owing to the diversity in practical applications, it cannot be resolved by conventional techniques [5]. Dynamic programming can deliver various degrees of success [6], however, these techniques suffer from the perspective of its dimensionality.

So far, the various known untainted stochastic approaches such as the Genetic Algorithm [7] (GA), Differential Evolution Algorithm [8] (DEA), Particle Swam Optimization [9] (PSO), Artificial Immune System [10] (AIS), Artificial Bee Colony Optimization [11] (ABCO), Ant Colony Optimization [12] (ACO) and Bacterial Foraging Optimization [13] (BFO) have been successfully employed to solve the PDED. However, these heuristic methods suffer in exploring the nearer optimal solution.

The sequentially based hybrid optimization technique integrates the different phases of techniques to optimize the problem. The different hybridized sequential technique includes GA-BFO [14], PSO-BFO [15], DESQP [16], TVAC-IPSO [17] and EP-SQP [18] is proposed for obtaining better quality solutions of DED problems. Although the sequential integration technique conveys superior quality results, it has certain deficiencies. Primarily, the merger points of these hybrid techniques spend more computation time. On the point of merger, the optimal solution may not be assured. All the above mentioned literature is mostly proposed to solve the PDED problem with standard test systems only. Therefore, it is essential to develop a new powerful technique to solve PDED problem. In this paper yet 
another technique is proposed to solve the practical generating system.

Most recently, a new optimization technique known as Bacterial Swarm Optimization (BSO) developed by Kevin M. Passino [19] has efficiently proposed a solution to various power system optimization problems. In the conventional Bacterial Swarm Optimization (BSO), the foraging behaviour of bacteria explores the global optimum solution, which is administered by inertial, cognitive and collective behaviour. The memory and collective behaviours are the main apparatuses of the foraging behaviour, which supports the swarm of bacteria to find nutrient gradients in optimal path.

The quorum-sensing is a biochemical communication, i.e. the process of generating, releasing, sensing and responding to small hormone-like molecules called autoinducers [20]. These molecules are the mediators of quorum sensing. The communication signalling permits bacteria to organize the behaviour of the group (swarming behaviour). In this QBSO formulation, the bacterium uses Quorum Signalling (QS) trajectories to remember the earlier visited noxious substances (worst fittest points) by comparing the earlier visited best position (high nutrient gradient) and worst position (noxious substances) components. This formulation is able to explore the best global position. The articulated technique is very operative in exploring the better search space and most suitable for exploring the global optimum solution of the proposed PDED problem with a public real time case.

In recent years, owing to rapidly increasing energy demand, the entire countries in the world are paying more attention to reducing the production cost for generating the electric power. Among all, India has become the world's third major electricity power producer in the year 2015. According to the central Electricity authority of India, the country is facing a power deficit of $5.1 \%$. The power generation companies are facing a lot of challenges to meet the increasing load demand. For balancing the demand, the power distribution companies create artificial load shedding to the customers. To provide customers with uninterrupted supply, the proper and precise scheduling of generating power with the available resources is the only choice.

India has adopted a blend of thermal, hydel, nuclear and other renewable energy sources. Out of these, thermal power plants have contributed a lot and been the backbone of the power generation. Hence, in this paper, thermal generating systems are considered for proper scheduling. In this, the major issues prevailing in the country are presented as follows. The electric power system of India is geologically segregated by complex linkage of generating stations. The whole power system is divided into five Regional grids comprising Northern Regional grid (NRG), Western Regional grid (WRG), Eastern Regional grid (ERG), Southern Regional grid (SRG) and North Eastern Regional grid (NERG). These grids were synchronized and connected to the central grid. In this paper the Southern Regional grid is considered for scheduling. The Southern Indian Regional Grid comprises the states of Andhra Pradesh, Telangana, Karnataka, Kerala, Tamilnadu and the union territory Puducherry. Among all these states, the board of electricity in
Tamilnadu state is facing a lot of challenges due to its increasing load demand. In this state, proper scheduling of all the generators is still under examination.

In this article, the main aim is to schedule 20 thermal generating units prevailing and contributing power to the Tamilnadu state. To authenticate the practicability, these thermal unit generators with different recorded load demand patterns are considered. The peak demand patterns are recorded from projected three major seasons. The generating entities owned by the state and central government with valve-point loading effect are considered. These entities are resolved to meet the load demands. Besides, the practical constraints which include power balance constraint, ramp rate limits and prohibited operating zones are accounted to encounter the solution. In most recent years, experimental attempts are enchanting to implement several procedures for better operation and control of the southern regional Grid (Tamilnadu). A maiden attempt is offered in this article to schedule these thermal generators of the Indian state Tamilnadu using the proposed technique.

\section{Dynamic power economic dispatch problem formulation}

The objective of the DPED problem is the kernel of the power system. This problem minimizes the operating generator fuel cost of committed units to meet the load demand, subject to equality and inequality constraints over a scheduled dispatch period.

The incremental fuel cost function of generating units and the major element of the operating costs for thermal units are usually given in a quadratic polynomial given by

$$
F_{\mathrm{T}}=\operatorname{Min} \sum_{h \in H} \sum_{i \in N_{\mathrm{G}}} F_{i h}\left(P_{i h}\right)=\sum_{h \in H} \sum_{i \in N_{\mathrm{G}}}\left(a_{i} P_{i h}^{2}+b_{i} P_{i h}+c_{i}\right), \$
$$

where $F_{\mathrm{T}}$ is the system total cost function over an entire dispatch period, $N_{\mathrm{G}}$ is the number of online thermal generators, $P_{i}$ is the power output of the generator $i, H$ is the number of horizons in the dispatched period, $a_{i}, b_{i}$ and $c_{i}$ are the operating cost coefficients. $F_{i h}\left(P_{i h}\right)$ is the fuel cost in terms of its real power output $P_{i h}$ at a particular hour $h$ (typically $1 \mathrm{hr}$ ).

Generally, large turbo generators have a set of valves at the inlet to the steam turbine. With the increase in power demand these valves are opened sequentially. This valve-opening process produces ripple like effect in the heat-rate curve of the generator. To consider the accurate cost curve of each generating unit, the valve-point effects must be included in the generator fuel cost. Therefore, conventional quadratic fuel-cost characteristic is overlaid with a repetitive rectified sinusoidal component that can be indicated as follows

$$
F_{\mathrm{T}}=\operatorname{Min} \sum_{h \in H} \sum_{i \in N_{\mathrm{G}}}\left(a_{i} P_{i h}^{2}+b_{i} P_{i h}+c_{i}+\mid e_{i} \sin \left(f_{i}\left(P_{i h}^{\mathrm{min}}-P_{i h}\right)\right)\right),
$$

Where $e_{i}, f_{i}$ are constants for the valve point effect of the generating unit $i$.

DPEDVL increases the non-linearity as well as a number of local optima in the search space. Similarly, the 
above mentioned solution methodology can easily trap in the local optima in the locality of optimal cost.

The DPED problem comprises the following constraints:

\subsection{Real power balance constraints}

The real power generated must be adequate enough to meet the system demand and network loss at particular dispatch interval (usually $1 \mathrm{hr}$ ). This equality constraint is formulated as follows

$$
\sum_{i \in N_{G}} P_{i h}=P_{\mathrm{D} h}+P_{\mathrm{L} h}, h=1,2, \ldots . ., H
$$

The network loss is the function of generator's power output and is intended by $B$ matrix loss formula, which is stated as

$$
P_{\mathrm{L} h}=\sum_{i \in N_{\mathrm{G}}} \sum_{j \in N_{\mathrm{G}}} P_{i h} B_{i j} P_{j h}+\sum_{i \in N_{\mathrm{G}}} B_{0 i} P_{i h}+B_{00}
$$

Where $P_{i h}, P_{j h}$ are real power injection at $i^{\text {th }}$ and $j^{\text {th }}$ buses at particular hour $h$ respectively, $B_{i j}$ is the component of square matrix $B$ of size $N_{\mathrm{G}}, B_{0 i}$ is the component of vector $B_{0}$ of length $N_{\mathrm{G}}$ and $B_{00}$ is a constant.

\subsection{Generator power constraints}

The real power output of each generator should be within its minimum and maximum limits. Corresponding inequality constraint constitute for each generator is

$P_{i}^{\mathrm{Min}} \leq P_{i h} \leq P_{i}^{\mathrm{Max}}, i=1,2, \ldots, N_{\mathrm{G}}$,

Where $P_{i}^{\mathrm{Min}}$ and $P_{i}^{\mathrm{Max}}$ are the minimum and maximum output of the $i^{\text {th }}$ generating unit, respectively

\subsection{Generator ramp rate constraints}

The generator with ramp rate limits of generating units is given as

When generation increases

$P_{i h}-P_{i(h-1)} \leq U R_{i}$

When generation decreases

$P_{i(h-1)}-P_{i h} \leq D R_{i}$

Where $U R_{i}$ and $D R_{i}$ are the ramp-up and ramp-down limits of $i^{\text {th }}$ generating unit in MW. Thus the constraints of Eq. (6) due to ramp rate constraints are modified as

$$
\operatorname{Max}\left\{P_{i, \mathrm{M} \mathrm{in}}, P_{i(h-1)}-D R_{i}\right\} \leq P_{i} \leq \operatorname{Min}\left\{P_{i, \mathrm{M} \mathrm{ax}}, P_{i(h-1)}+U R_{i}\right\}
$$

\subsection{Prohibited operating zones constraint}

The Real-world generating units have prohibited operating zones due to physical operational constraints such as faults in the machines themselves or the auxiliary equipment, such as boiler and feed pumps. A generating unit that operates in these zones could experience intensity of vibrations in its shaft bearing. To evade operating in these zones, the generating unit has irregular input-output characteristics given by

$$
P_{i h} \in\left\{\begin{array}{l}
P_{i}^{\mathrm{Min}} \leq P_{i} \leq P_{i, 1}^{l} \\
P_{i, k-1}^{u} \leq P_{i} \leq P_{i, k}^{l}, k=2,3, \ldots, p z_{i} \\
P_{i, X_{i}}^{u} \leq P_{i} \leq P_{i}^{\mathrm{Max}}, i=1,2, \ldots, n_{p z}
\end{array}\right.
$$

Where $n_{p z}$ is the number of prohibited zones for $i^{\text {th }}$ generating unit, $P_{i, k}^{l}$ and $P_{i, k}^{u}$ are the lower and upper bounds of the $k^{\text {th }}$ prohibited zone of $i^{\text {th }}$ generating unit.

\subsection{Evaluating the proposed optimization problem}

The proposed objective function is estimated by evaluating the bacteria's fitness in the solution search space. The problem represents the addition of the incremental fuel cost function with valve- point loading effect and constraints. The constraints include real power balance, generator power, ramp rate and prohibited operating limits. The proposed optimization problem comprises the following:

$\operatorname{Min} F_{\mathrm{opt}}=F_{\mathrm{T}}+P_{i h}$,

Where $F_{\mathrm{T}}=\sum_{h \in H} \sum_{i \in N_{\mathrm{G}}} F_{i h}\left(P_{i h}\right)$

In order to limit the objective function, the highest fitness value of each bacterium is chosen within the optimization search space. The power generated output need to satisfy the generator ramp rate and prohibited operating constraints.

\section{Conventional Bacterial Swarm Optimization}

Bacterial Swarm Optimization is a new simple stochastic search technique widely employed for solving distributed optimization and control [21]. The main idea of the BSO is the accurate modelling and simulation of the food searching strategy of bacterial swarm. The simple biological foraging behaviour helps the researchers to solve real-world optimization problems. Every single bacterium signifies a feasible solution to the optimization problems. The bacteria swarm towards the random directions in the search space [22] and always forage towards the nutrient gradient in optimal path. The swarming of bacteria is influenced by three major mechanisms, namely velocity, cognitive and social behaviours. The inertial component represents the motile nature of bacteria to swim and tumble in the previous visited direction. The cognitive and collective component signifies the bacteria's memory about its previous best location and the memory about the best location of the swarm. Tumbling around the search space, the bacteria try to discover the best optimal solution (high nutrient concentration). From these behaviours, the novel BSO is modelled as follows 


$$
\begin{aligned}
& J^{S W}(i, j, k, l)=\sum_{i=1}^{N B} J_{c c}(\theta(i, j, k, l)= \\
& =\left[\begin{array}{l}
\sum_{i=1}^{N B}\left[d_{\text {attract }} \cdot \exp \left(w_{\text {attract }} \sum_{m=1}^{n}\left(\theta_{\text {gbest }}-\theta_{\text {best }}^{i}\right)\right]+\right. \\
\sum_{i=1}^{N B}\left[h_{\text {repellant }} \cdot \exp \left(w_{\text {repellant }} \sum_{m=1}^{n}\left(\theta_{\text {gbest }}-\theta_{\text {best }}^{i}\right)^{2}\right)\right]
\end{array}\right]
\end{aligned}
$$

The cognitive and collective behaviours are the two main mechanisms of the foraging activity of the bacterial swarm. By controlling these behaviours, the exploration capability of bacteria can be improved.

\section{Proposed quorum sensing based bacterial swarm optimization}

The Quorum sensing is natural among bacteria and helps to retain the bacteria in a good location. This assists the bacterial swarm from congestion (overcrowding) and avoids from noxious substances [23]. The newly presented variants with quorum sensing enabled bacterial swarm optimization consistently trying to chase the more nutrient gradient locations and avoiding harmful matters. The proposed method models the bacteria's best and worst location. These locations identify the global best location. It is demonstrated by segregating both the memory and collective behaviours components of the conventional $\mathrm{BSO}$. In the cognitive behaviour, the bacterial swarm collects both the best and worst experience position among the search space. When exploring, the bacteria remember earlier visited best position (high nutrient gradient) and previously visited worst position (noxious substance). Based on these positions bacteria always explore towards the global best position in the selected search space. Correspondingly, the bacteria's collective behaviour is distributed into global best and worst experience mechanisms. The diffusion of noxious substances and the motion pattern will affect the grouping behaviour and move the bacteria towards complex paths. The projected QBSO variant deliberates these cognitive and grouping components to calculate the inertial movement of bacteria.

Then, the inertial update equation for the proposed technique is given by

$$
\begin{aligned}
& J^{S W}(i, j, k, l)=\sum_{i=1}^{N B} J_{c c}(\theta(i, j, k, l))= \\
& =\left[\sum_{i=1}^{N B}\left[r_{1} \cdot d_{\text {attract }} \cdot \exp \left(w_{\text {attract }} \cdot \sum_{m=1}^{n}\left[\theta_{\text {gbest }}-\theta_{\text {best }}^{i}\right)^{2}\right)+r_{2} \cdot\left(\theta_{\text {best }}^{i}-\theta_{\text {worst }}^{i}\right)\right]+\right. \\
& \left.\left.\sum_{i=1} \cdot h_{\text {repellant }} \cdot \exp \left(w_{\text {repellant }} \cdot \sum_{m=1}^{n}\left(\theta_{\text {gbest }}-\theta_{\text {best }}^{i}\right)^{2}\right)+r_{4} \cdot\left(\theta_{\text {best }}^{i}-\theta_{\text {worst }}^{i}\right)\right]\right]
\end{aligned}
$$

where $r_{1}, r_{2}, r_{3}$ and $r_{4}$ are the random values generated within 0 and 1 .The bacterial position is updated by using the equation

$$
\theta(i, j+1, k, l)=\theta(i, j, k, l)+C(i) \cdot \frac{\Delta(i)}{\sqrt{\Delta^{\mathrm{T}}(i) \cdot \Delta(i)}}
$$

By knowing the worst experience components the bacterial swarm spends surplus exploration capability to the swarming behaviour. Through the worst experience positions, the bacteria continually try to avoid its previous worst positions (noxious substance locations) and move towards healthier location in the area of the search space (high nutrient gradient), i.e., finding the global best position in the search space.

\section{Implementation of QBSO for DPED problems}

This section delivers the solution methodology to the above-mentioned DPED problem through QBSO.

Step1: Initialization of the bacterial swarm behaviour

Initially the $N B$ number of bacteria is randomly generated and positioned at random locations in the search space. Here the $N B$ represents the $N_{\mathrm{G}}$ generators involved in the schedule. The bacterial position is characterized as an initial vector of length $N_{\mathrm{G}}$ generating units and having $H$ Horizons and $N_{\mathrm{G}}$ generation schedules. The initial position vector can be represented as

Bacterial position $=\left[\begin{array}{cccc}\theta_{11} & \theta_{12} & \cdots & \theta_{1 H} \\ \theta_{21} & \theta_{22} & \cdots & \theta_{2 H} \\ \vdots & \vdots & \ddots & \vdots \\ \theta_{N_{\mathrm{G}} 1} & \theta_{N_{\mathrm{G}} 2} & \cdots & \theta_{N_{\mathrm{G}} H}\end{array}\right]$

Each vector elements must satisfy the equality and inequality constraints.

Step 2: Constraints considered for DPED problem

The positioned bacteria should satisfy the following constraints. For all these constraints, consider the generating units number $i=1$.

Equality Constraint:

\section{(i) Power balance constraint}

In this the scheduled generated power at $\mathrm{h}$ hour $\left(P_{i h}\right)$ should satisfy the load demand $\left(P_{\text {Demand }}\right)$ and the transmission loss $\left(P_{\text {Loss } h}\right)$ incurred.

Furthermore this constraint is controlled by a criticized constant $\lambda_{\mathrm{PF}}$. This criticized objective function is formulated as

$$
C F_{\mathrm{T}}=\sum_{i \in N_{G}} F_{i}\left(P G_{i}\right) \lambda_{\mathrm{PF}} \cdot\left[\left|\sum_{i \in N_{G}} P_{\mathrm{G} i}=P_{\text {Demand } h}+P_{\mathrm{Loss} h}\right|\right]
$$

Inequality constraints:

\section{(ii) Generator power operating constraints}

The power output of the generator should be within the minimum $P_{i h}^{\mathrm{Min}}$ and maximum $P_{i h}^{\mathrm{Max}}$ operating limits.

\section{(iii) Ramp rate constraints}

If the initial dispatch horizon $h=1$. At that time fix $P_{i h}^{\operatorname{Max}}=P_{i}^{\operatorname{Max}}$ and $P_{i h}^{\text {Min }}=P_{i}^{\text {Min }}$

If the dispatch horizon does not satisfy, then set $P_{i h}^{M i n}=\operatorname{Max}\left\{P_{i, \operatorname{Min}}, P_{i(h-1)}-D R_{i}\right\}$ and

$P_{i h}^{M a x}=\operatorname{Min}\left\{P_{i, \operatorname{Max}}, P_{i(h-1)}+U R_{i}\right\}$ 
(iv) The generated power of each horizon should satisfy the prohibited operating zone constraints. The promising zones are given by Eq. (8).

\section{Step 3: Estimation of fitness function}

The fitness of bacteria is accomplished by minimizing the objective function of DPED.

Fitness Function $=1 /($ DPEDVL + Equality and Inequality Constraints)

\section{Step 4: Locating best and worst bacteria}

Initially the $\theta_{\text {best }}$ and $\theta_{\text {worst }}$ for all bacteria are randomly located on the initial locations in the search space. From the proposed approach, the position of bacteria with least criticized objective function is the bacteria's best position $\theta_{\text {best }}$. The best position available throughout the search space is taken as $\theta_{\text {gbest }}$. Criticized objective function of the global best position is taken as $F \theta_{\text {gbest }}$. Similarly, the worst position $\theta_{\text {worst }}$ among the search space is grabbed as $\theta_{\text {gworst }}$. These worst positions are considered for finding global best position amongst all.

\section{Step 5: Swarming behaviour of bacteria}

The bacteria assist with swimming and tumbling moves towards better position. This movement is presented by inertial update equation specified in Eq. (11). The position update equation is taken at Eq. (12). Suppose the bacterial position $\theta_{i H}$ violates the generator real power limits, the position is fixed at the border value.

\section{Step 6: Selection and reproduction}

Based on the least accumulated fitness function the bacteria population (healthy bacteria) is selected. This specifies the bacteria with most success. The bacteria with the highest fitness (unhealthy bacteria) are discarded. The healthy bacteria with good cognitive sense and collective behaviour are retained and the copy of the healthiest is placed in the location of discarded bacteria.

\section{Step 7: Termination condition}

In the proposed technique, if the maximum number of iterations is reached, then the algorithm is terminated. If the termination condition is not fulfilled, then the QBSO algorithm steps are reiterated with the same steps mentioned above. Then, $\theta_{\text {gbest }}$ is the optimum generation schedule of online generators and $F \theta_{\text {gbest }}$ is the minimum fuel generating cost.

\section{Results and discussion}

The effectiveness of the proposed approach has been executed on a test system and programmed using practical South Indian public thermal generating system. The system has been MATLAB 8.1.0.604 (R2013a) environment with Intel, Core 2 Duo CPU@2.40 GHz personal computer with 2 GB RAM.

Table 1 Parameters considered for proposed technique.

\begin{tabular}{|l|c|}
\hline \multicolumn{1}{|c|}{ Parameters } & $\begin{array}{c}\text { Value } \\
\text { Considered }\end{array}$ \\
\hline Number of Bacteria $(N B)$ & 20 \\
\hline Depth of the Attractant Signal $\left(d_{\text {attract }}\right)$ & 0,01 \\
\hline Width of the Attractant Signal $\left(w_{\text {attract }}\right)$ & 0,4 \\
\hline Height of the Repellent Effect $\left(h_{\text {repellent }}\right)$ & 0,1 \\
\hline Swimming Length $\left(N_{\mathrm{s}}\right)$ & 20 \\
\hline Chemotactic Steps $\left(N_{\mathrm{ch}}\right)$ & 15 \\
\hline Reproduction Steps $\left(N_{\mathrm{re}}\right)$ & 4 \\
\hline Elimination-Dispersal events $\left(N_{\mathrm{ed}}\right)$ & 5 \\
\hline Maximum Iterations taken & 100 \\
\hline
\end{tabular}

\subsection{QBSO control parameters considered}

Based on the results of mathematical formulation and numerical simulation test, the QBSO parameters considered are shown in Tab. 1.

\subsection{Nominal test case ( 10 Thermal generating system)}

In this test case, a 10 thermal generating system [18] is determined for DED with valve-point loading effect, transmission losses, real power balance, generator output limits and unit ramp rate limits are taken into account. The transmissions B-loss Matrix are indicated in [24]. In the proposed method effectiveness is acquired by simulating the QBSO technique for 40 trials and the corresponding optimum results are presented in Fig. 1. From the obtained simulation trials, the best optimal fuel cost is acquired as $1041054 \$$, the average fuel cost is 1042097 \&, the worst fuel cost is 1043596 \$ and the best CPU run time is $0,598 \mathrm{~min}$. The results are evidently realised that of the proposed QBSO and simulated BSO techniques attains high worthy solutions than earlier proposed techniques such as EP, EP-SQP, AIS, GA and IPSO. Besides it minimizes the total fuel cost more significantly and the results are shown in variance Tab. 2 . Thus, the new projected QBSO technique offers more efficient and economical total fuel cost than the conventional BSO method.

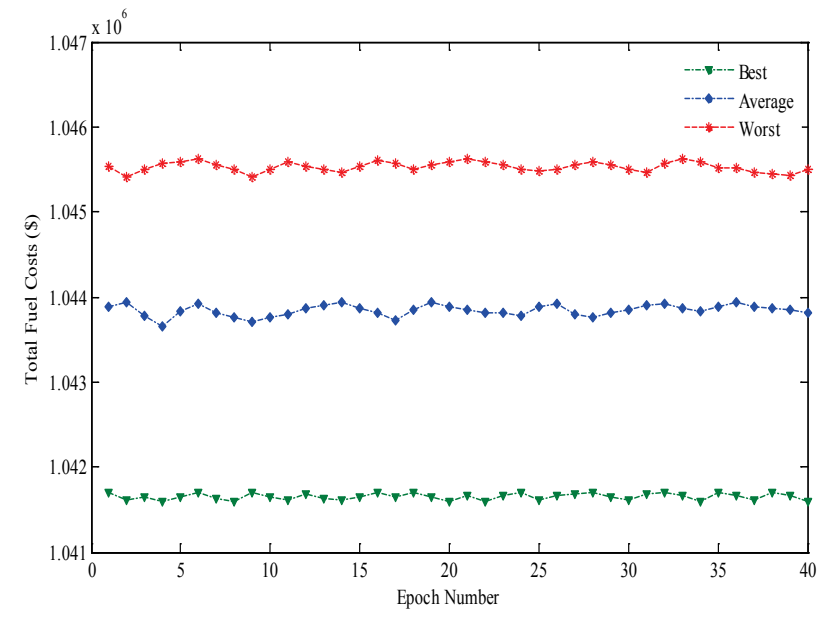

Figure1 Best, average and worst fuel cost distribution acquired by QBSO of each epoch for 10-Thermal units

The best power generation schedule for 24 hours is offered in Tab. 3. The generated power output of the respective thermal generating unit fulfils the generator power balance, ramp rate constraints. From Fig. 2 the following conclusions are made to this enhanced variant: Initially, for the least amount of bacterial population employed and for minimum number of algorithm iterations, the quorum sensing mechanism based proposed methodology can improve the convergence property for each dispatch horizon. Furthermore, this inclusion avoids the premature convergence and improves the exploration capability of the algorithm. 
Table 2 Results obtained for DPED problem for 10 thermal units

\begin{tabular}{|c|c|c|c|c|}
\hline \multirow[b]{2}{*}{$\begin{array}{c}\text { Solution } \\
\text { methodology }\end{array}$} & \multicolumn{3}{|c|}{ Total operation costs $(\$)$} & \multirow{2}{*}{$\begin{array}{c}\text { Best } \\
\text { CPU } \\
\text { run } \\
\text { time } \\
\text { (min) }\end{array}$} \\
\hline & Best cost & Mean cost & Worst cost & \\
\hline $\mathrm{EP}[18]$ & 1054685 & 1057323 & $\mathrm{NP} *$ & 47,230 \\
\hline EP-SQP [18] & 1052668 & 1053771 & $\mathrm{NP}^{*}$ & 27,53 \\
\hline AIS [10] & 1045715 & 1047050 & 1048431 & 23,220 \\
\hline PSO [11] & 1048410 & 1052092 & 1057170 & 4,0933 \\
\hline GA [11] & 1052251 & 1058041 & 1062511 & 3,4436 \\
\hline IPSO [25] & 1046275 & 1048145 & NP* & NP* \\
\hline $\begin{array}{l}\text { BSO } \\
\text { (Proposed) }\end{array}$ & 1042896 & 1044682 & 1046275 & 1,565 \\
\hline $\begin{array}{l}\text { QBSO } \\
\text { (Proposed) }\end{array}$ & 1041054 & 1042097 & 1043596 & 0,598 \\
\hline
\end{tabular}

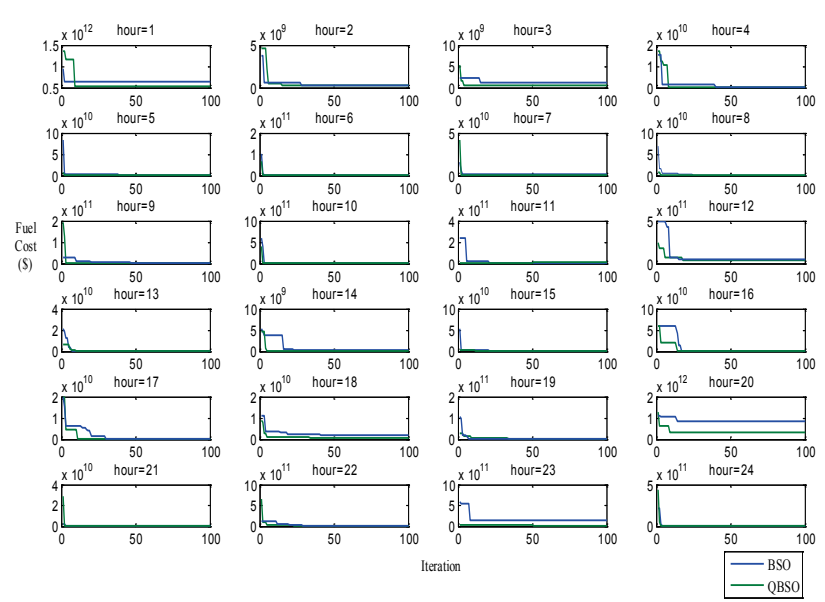

Figure 2 The result comparison of standard BSO and projected QBSO of nominal 10thermal units for each 24 dispatch hours

\subsection{Practical case (20 South Indian thermal generating system)}

To exhibit the effectiveness of the proposed QBSO technique the increased number of system with real-world thermal generating unit (Tamilnadu State, India) is taken into consideration. The considered thermal units have been scheduled and satisfy the load demand prevailing in the Tamilnadu state. For this the load demand patterns are recorded based on the climatic conditions of India. The weather situation in India is distributed into three diverse seasons generally summer (From March to May), monsoon (From June to October) and the winter (From November to February). For this case, the peak load demand months of three different seasons, typically April, August and December, and its demand profile of each month peak day is recorded (load demand data is offered by the state electricity board of Tamil Nadu Generation and Distribution Corporation Limited). The load demands characteristics of these seasons shown in Fig. 3 are taken into account. The projected three load demand profiles are unique in their characteristics.

In the optimization point of view, from Fig. 3, the load demand profile 1 (Month April) has double valleys and double peak demand variations in the 24 hour schedule horizon. Load profile 2 (Month August) has single valley and single peak demand deviations in the whole horizon. The demand profile 3 (Month December) has three drooping valleys and two peak demand variations in the complete schedule period. These valleys and peaks are best suited to test the proposed optimization technique to find a global best optimal solution. The practicability of the proposed technique is authenticated for these load demand profiles. This paper attempts to project and schedule the twenty various thermal power stations situated and contributing power to all the portions of Tamilnadu state. These thermal generating unit data are anticipated based on the capacity of generating stations (Data Offered by Tamilnadu Generation and Distribution Corporation [TANGEDCO]) and the losses in the transmission line are rounded to $15 \%$ as per the TANGEDCO figures.

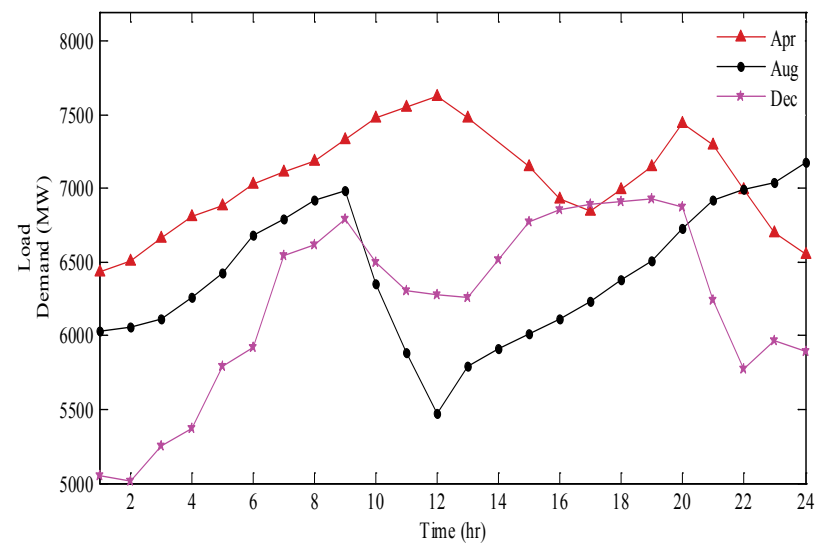

Figure3 Load profile recorded from a peak demand day of a month in summer, monsoon and winter

The practically recorded demand profiles for three different seasons include 7628, 7176 and 6930 MWs correspondingly. Tab. 3 provides the best thermal generating units schedule attained by the proposed method with losses for load demand profile 1 .

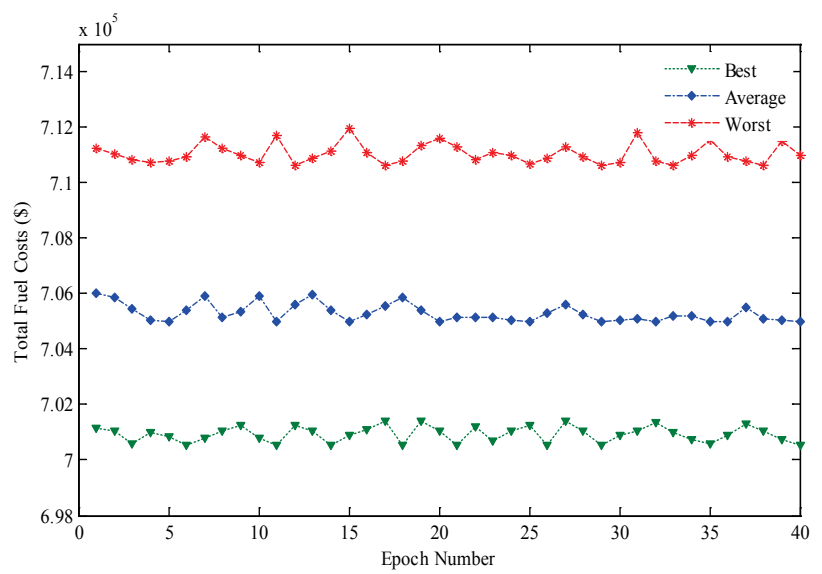

Figure 4 Best average and worst fuel cost distribution acquired by QBSO of each epoch for practical case with profile 1

The best total fuel cost of thermal generators by proposed QBSO technique for load demand profiles 1, 2, 3 is $700555,52 \$, 557072,88 \$$ and $617948,10 \$$. The average fuel cost for the above mentioned three demand profiles includes $704996,48 \$, 573118,42 \$$ and $629846,99 \$$. The worst fuel cost for profile corresponds $710624,48 \$$, $595274,56 \$$ and $641759,59 \$$ respectively. In order to validate the efficiency of the proposed method, the optimum results are acquired by simulating 40 trails and the results are presented in Figs. 4, 5 and 6. From the simulation results it is evident that 
the proposed QBSO method produces quality results above $75 \%$ as seen from the presented figures below.

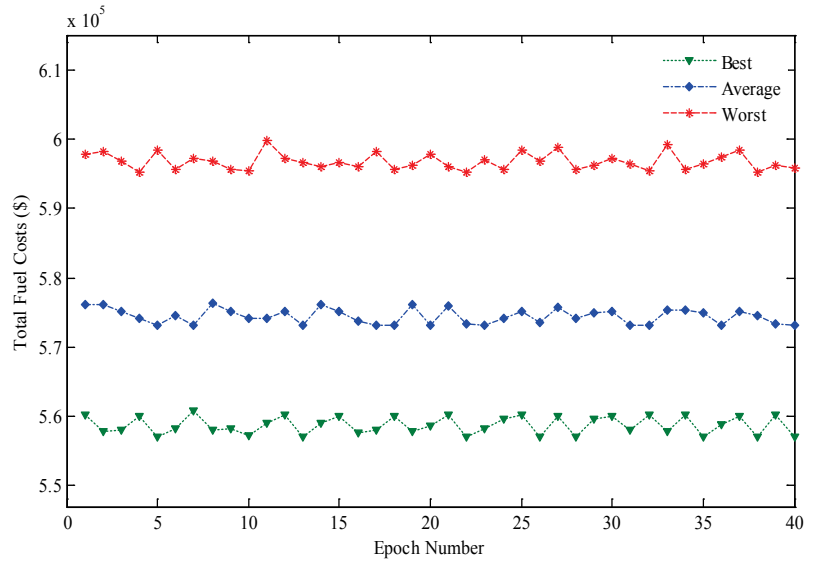

Figure 5 Best average and worst fuel cost distribution acquired by QBSO of each epoch for practical case with profile 2

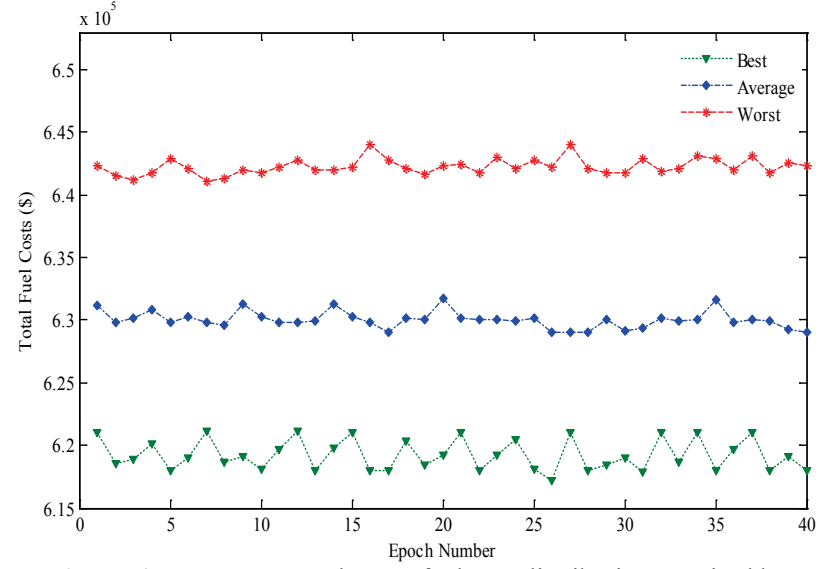

Figure 6 Best average and worst fuel cost distribution acquired by QBSO of each epoch for practical case with profile 3

Table3 Best generation schedule found by QBSO for DPED (20 Practical thermal units with losses)

\begin{tabular}{|c|c|c|c|c|c|c|c|c|c|c|}
\hline Hour & $\begin{array}{l}\text { Unit } 1 \\
\text { (MW) }\end{array}$ & $\begin{array}{l}\text { Unit } 2 \\
\text { (MW) }\end{array}$ & $\begin{array}{l}\text { Unit } 3 \\
\text { (MW) }\end{array}$ & $\begin{array}{l}\text { Unit } 4 \\
(\mathrm{MW}) \\
\end{array}$ & $\begin{array}{l}\text { Unit } 5 \\
\text { (MW) }\end{array}$ & $\begin{array}{l}\text { Unit } 6 \\
\text { (MW) }\end{array}$ & $\begin{array}{l}\text { Unit } 7 \\
\text { (MW) }\end{array}$ & $\begin{array}{l}\text { Unit } 8 \\
\text { (MW) }\end{array}$ & $\begin{array}{l}\text { Unit } 9 \\
(\mathrm{MW})\end{array}$ & $\begin{array}{l}\text { Unit10 } \\
\text { (MW) }\end{array}$ \\
\hline 1 & 175,82 & 170,00 & 210,00 & 205,15 & 210,00 & 414,28 & 309,26 & 607,85 & 452,24 & 551,00 \\
\hline 2 & 155,59 & 160,00 & 140,00 & 160,23 & 210,00 & 420,00 & 370,88 & 620,00 & 440,16 & 600,00 \\
\hline 3 & 155,59 & 160,00 & 136,98 & 199,35 & 210,00 & 398,36 & 378,99 & 620,00 & 439,79 & 596,00 \\
\hline 4 & 179,45 & 210,00 & 210,00 & 183,45 & 210,00 & 416,23 & 409,39 & 619,86 & 490,33 & 556,00 \\
\hline 5 & 180,00 & 180,87 & 210,00 & 203,25 & 210,00 & 420,00 & 413,67 & 619,86 & 459,48 & 556,00 \\
\hline 6 & 179,68 & 208,99 & 210,00 & 203,23 & 210,00 & 420,00 & 405,07 & 619,86 & 423,87 & 550,91 \\
\hline 7 & 199,65 & 246,69 & 160,00 & 202,34 & 145,72 & 415,56 & 416,46 & 740,00 & 425,63 & 600,00 \\
\hline 8 & 198,34 & 208,84 & 196,38 & 194,01 & 210,00 & 420,00 & 419,32 & 709,64 & 477,25 & 597,49 \\
\hline 9 & 192,36 & 180,65 & 210,00 & 181,55 & 198,92 & 368,65 & 392,44 & 739,00 & 468,19 & 558,84 \\
\hline 10 & 195,46 & 189,00 & 194,00 & 205,04 & 210,00 & 378,56 & 414,61 & 737,36 & 597,14 & 600,00 \\
\hline 11 & 195,62 & 205,77 & 209,67 & 194,60 & 210,00 & 415,98 & 418,98 & 727,00 & 560,81 & 600,00 \\
\hline 12 & 198,54 & 208,58 & 208,84 & 195,49 & 210,00 & 415,98 & 414,58 & 727,00 & 596,01 & 596,00 \\
\hline 13 & 199,78 & 210,00 & 208,65 & 170,26 & 210,00 & 414,65 & 414,80 & 727,00 & 585,48 & 552,00 \\
\hline 14 & 165,26 & 212,47 & 208,00 & 179,12 & 210,00 & 415,98 & 420,77 & 727,00 & 471,69 & 552,00 \\
\hline 15 & 158,64 & 210,00 & 184,00 & 169,72 & 210,00 & 415,98 & 422,97 & 717,00 & 422,66 & 552,00 \\
\hline 16 & 169,37 & 212,41 & 184,00 & 110,16 & 210,00 & 403,86 & 376,59 & 620,00 & 507,55 & 552,00 \\
\hline 17 & 182,85 & 196,55 & 184,00 & 142,07 & 210,00 & 415,98 & 307,83 & 620,00 & 507,55 & 552,00 \\
\hline 18 & 175,36 & 145,34 & 210,00 & 129,79 & 210,00 & 415,98 & 238,66 & 714,68 & 507,55 & 552,00 \\
\hline 19 & 188,96 & 206,04 & 210,00 & 153,89 & 210,00 & 420,00 & 377,81 & 712,00 & 507,55 & 552,00 \\
\hline 20 & 189,63 & 210,00 & 210,00 & 210,82 & 210,00 & 420,00 & 420,92 & 712,00 & 598,57 & 600,00 \\
\hline 21 & 185,56 & 199,04 & 210,00 & 136,18 & 210,00 & 420,00 & 441,47 & 712,00 & 562,42 & 600,00 \\
\hline 22 & 178,62 & 176,69 & 210,00 & 162,48 & 210,00 & 420,00 & 351,61 & 618,62 & 385,66 & 600,00 \\
\hline 23 & 178,62 & 172,69 & 210,00 & 190,92 & 210,00 & 420,00 & 331,80 & 618,62 & 380,66 & 545,00 \\
\hline 24 & 176,89 & 176,69 & 196,62 & 140,10 & 145,52 & 420,00 & 353,05 & 618,62 & 380,66 & 550,92 \\
\hline
\end{tabular}

Table3 Best generation schedule found by QBSO for DPED (20 Practical thermal units with losses) (continuation)

\begin{tabular}{|c|c|c|c|c|c|c|c|c|c|c|}
\hline Hour & $\begin{array}{c}\text { Unit 11 } \\
(\mathrm{MW})\end{array}$ & $\begin{array}{c}\text { Unit 12 } \\
(\mathrm{MW})\end{array}$ & $\begin{array}{c}\text { Unit 13 } \\
(\mathrm{MW})\end{array}$ & $\begin{array}{c}\text { Unit 14 } \\
(\mathrm{MW})\end{array}$ & $\begin{array}{c}\text { Unit 15 } \\
(\mathrm{MW})\end{array}$ & $\begin{array}{c}\text { Unit 16 } \\
(\mathrm{MW})\end{array}$ & $\begin{array}{c}\text { Unit 17 } \\
(\mathrm{MW})\end{array}$ & $\begin{array}{c}\text { Unit 18 } \\
(\mathrm{MW})\end{array}$ & $\begin{array}{c}\text { Unit 19 } \\
(\mathrm{MW})\end{array}$ & $\begin{array}{c}\text { Unit 20 } \\
(\mathrm{MW})\end{array}$ \\
\hline 1 & 420,00 & 397,62 & 210,00 & 400,00 & 380,00 & 120,00 & 230,89 & 200,00 & 340,00 & 432,15 \\
\hline 2 & 499,56 & 393,26 & 208,00 & 484,69 & 337,86 & 120,00 & 200,44 & 209,67 & 340,00 & 440,00 \\
\hline 3 & 600,00 & 404,27 & 198,63 & 600,00 & 340,94 & 120,00 & 228,61 & 198,41 & 340,00 & 334,85 \\
\hline 4 & 600,00 & 412,36 & 210,00 & 451,48 & 314,94 & 120,00 & 213,18 & 198,41 & 340,00 & 440,00 \\
\hline 5 & 587,26 & 413,67 & 210,00 & 401,23 & 434,94 & 120,00 & 193,92 & 198,41 & 340,00 & 535,00 \\
\hline 6 & 590,58 & 415,07 & 209,73 & 530,00 & 420,56 & 119,78 & 247,00 & 210,48 & 360,00 & 534,96 \\
\hline 7 & 600,00 & 416,98 & 209,93 & 539,96 & 420,56 & 120,00 & 179,61 & 219,06 & 360,00 & 492,25 \\
\hline 8 & 584,96 & 412,55 & 209,93 & 545,64 & 598,56 & 120,00 & 180,05 & 219,06 & 346,16 & 335,65 \\
\hline 9 & 600,00 & 409,07 & 209,03 & 598,63 & 596,62 & 120,00 & 179,87 & 219,06 & 360,00 & 550,00 \\
\hline 10 & 550,04 & 406,71 & 210,00 & 593,00 & 594,86 & 120,00 & 196,45 & 219,06 & 360,00 & 509,23 \\
\hline 11 & 598,67 & 393,37 & 206,65 & 591,78 & 595,00 & 120,00 & 194,84 & 219,06 & 346,48 & 550,00 \\
\hline 12 & 594,78 & 415,10 & 210,00 & 594,68 & 595,00 & 120,00 & 199,35 & 219,06 & 360,00 & 550,00 \\
\hline 13 & 528,00 & 413,26 & 209,95 & 546,00 & 595,00 & 120,00 & 245,78 & 220,00 & 360,00 & 550,00 \\
\hline 14 & 528,00 & 414,07 & 209,95 & 549,00 & 594,89 & 120,00 & 237,25 & 220,00 & 360,00 & 537,00 \\
\hline 15 & 528,00 & 412,01 & 209,95 & 549,00 & 595,00 & 120,00 & 155,01 & 220,00 & 360,00 & 537,00 \\
\hline
\end{tabular}


Table 3 Best generation schedule found by QBSO for DPED (20 Practical thermal units with losses) (continuation 1)

\begin{tabular}{|c|c|c|c|c|c|c|c|c|c|c|}
\hline Hour & $\begin{array}{c}\text { Unit 11 } \\
(\mathrm{MW})\end{array}$ & $\begin{array}{c}\text { Unit 12 } \\
(\mathrm{MW})\end{array}$ & $\begin{array}{c}\text { Unit 13 } \\
(\mathrm{MW})\end{array}$ & $\begin{array}{c}\text { Unit 14 } \\
(\mathrm{MW})\end{array}$ & $\begin{array}{c}\text { Unit 15 } \\
(\mathrm{MW})\end{array}$ & $\begin{array}{c}\text { Unit 16 } \\
(\mathrm{MW})\end{array}$ & $\begin{array}{c}\text { Unit 17 } \\
(\mathrm{MW})\end{array}$ & $\begin{array}{c}\text { Unit 18 } \\
(\mathrm{MW})\end{array}$ & $\begin{array}{c}\text { Unit } 19 \\
(\mathrm{MW})\end{array}$ & $\begin{array}{c}\text { Unit 20 } \\
(\mathrm{MW})\end{array}$ \\
\hline 16 & 528,00 & 413,36 & 209,48 & 549,00 & 524,00 & 120,00 & 120,22 & 220,00 & 360,00 & 537,00 \\
\hline 17 & 528,00 & 409,09 & 209,48 & 549,00 & 527,00 & 120,00 & 158,89 & 220,00 & 272,78 & 537,00 \\
\hline 18 & 528,00 & 409,09 & 209,48 & 549,00 & 527,00 & 120,00 & 228,70 & 220,00 & 358,00 & 549,79 \\
\hline 19 & 517,00 & 409,09 & 209,48 & 525,00 & 527,00 & 120,00 & 170,49 & 220,00 & 360,00 & 550,00 \\
\hline 20 & 517,00 & 459,73 & 209,48 & 525,00 & 527,00 & 120,00 & 185,37 & 220,00 & 360,00 & 537,00 \\
\hline 21 & 517,00 & 384,46 & 202,56 & 524,69 & 595,78 & 120,00 & 170,41 & 220,00 & 346,16 & 537,00 \\
\hline 22 & 517,00 & 443,65 & 208,74 & 524,69 & 587,53 & 120,00 & 195,05 & 198,96 & 360,00 & 529,00 \\
\hline 23 & 517,00 & 390,82 & 194,48 & 400,69 & 520,62 & 120,00 & 235,01 & 196,91 & 340,00 & 529,00 \\
\hline 24 & 501,03 & 375,31 & 181,65 & 525,00 & 520,62 & 75,44 & 152,42 & 195,82 & 338,96 & 529,00 \\
\hline
\end{tabular}

The CPU run times for three demand profiles are presented in Tab. 4.

Table 4 Best CPU run time for practical generating system

\begin{tabular}{|c|c|}
\hline Load Demand Profile & Time (min) \\
\hline Profile 1 & 0,5842 \\
\hline Profile 2 & 0,6020 \\
\hline Profile 3 & 0,6264 \\
\hline
\end{tabular}

The projected QBSO technique can allocate the economic scheduling of generators and minimize the thermal fuel cost more extensively than the manual scheduling method.

\section{Conclusion}

This paper proposes the new enhanced QBSO technique to solve the real-world PDED problem. The practicability of projected QBSO technique is validated on a standard 10 unit system and a practical 20 thermal generating units for the recorded load demand profiles. The result clearly indicates that the proposed technique is superior while handling complex real time generating system with constraints. The results illustrate the superiority of the proposed QBSO technique compared with conventional BSO and other techniques reported in literature. This technique may be applied to schedule the system with large number of generators. Due to the massive complex networks and increasing load demands in Southern Regional Grid, a suitable scheduling model in this grid is still under study. Thus the projected technique is capable of generating higher quality solutions and schedules the generators optimally so that the available demands are satisfied. Thereby, the accurate scheduling of generators saves the significant expenses to TANGEDCO limited.

\section{Acknowledgements}

The authors would be very grateful to Mr.N.S. Namasivayam chairman, board of Electricity Generation and Distribution Corporation of Tamilnadu, India for his generous support and statistical data provided for executing 20 South Indian thermal generating system in the proposed method.

\section{References}

[1] Hindi, K. S.; Ab Ghani, M. R. Dynamic Economic Dispatch for Large Scale Power Systems: a Lagrangian Relaxation Approach. // International Journal of Electrical Power and
Energy Systems. 13, 1(1991), pp. 51-56. DOI: 10.1016/01420615(91)90018-Q

[2] Lee, F. N.; Lemonidis, L.; Liu, K. Price-Based Ramp-Rate Model for Dynamic Dispatch and Unit Commitment. // IEEE Transactions on Power Systems. 9, 3(1994), pp. 1233-1242. DOI: 10.1109/59.336075

[3] Yuan, X.; Wang, L.; Yuan Y.; Zhang Y.; Cao B.; Yang B. A Modified Differential Evolution Approach for Dynamic Economic Dispatch with Valve-Point Effects. // Energy Conversation and Management. 49, (2008), pp. 3447-3453. DOI: 10.1016/j.enconman.2008.08.016

[4] Xia, X.; Elaiw, A. M. Optimal Dynamic Economic Dispatch of Generation: A Review. // Electrical Power System Research. 80, (2010), pp. 975-986. DOI: 10.1016/j.epsr.2009.12.012

[5] Jabr, R. A.; Coonick, A. H.; Cory, B. J. A Homogeneous Linear Programming Algorithm for the Security Constrained Economic Dispatch Problem. // IEEE Transactions on Power System. 15, (2000), pp. 930-936. DOI: $10.1109 / 59.871715$

[6] Travers, D. L.; Kaye, R. Dynamic Dispatch by Constructive Dynamic Programming. // IEEE Transactions on Power System. 13, 4(1998), pp. 72-78. DOI: 10.1109/59.651616

[7] Chiang, C. Improved Genetic Algorithm for Power Economic Dispatch of Units with Valve-Point Effects and Multiple Fuels. // IEEE Transactions on Power Systems. 20, 4(2005), pp. 1690-1699. DOI: 10.1109/TPWRS.2005.857924

[8] Coelho, L. D. S.; Mariani, V. C. Improved Differential Evolution Algorithms for Handling Economic Dispatch Optimization with Generator Constraints. // Energy Conversation and Management. 48, (2007), pp. 1631-1639. DOI: 10.1016/j.enconman.2006.11.007

[9] Cai, J.; Ma, X.; Li, L.; Haipeng, P. Chaotic Particle Swarm Optimization for Economic Dispatch Considering the Generator Constraints. // Energy Conversation and Management. 48, (2007), pp. 645-653. DOI: 10.1016/j.enconman.2006.05.020

[10] Hemamalini, S.; Simon, S. P. Dynamic economic dispatch using artificial immune system for units with valve-point effect. // International Journal of Electrical Power \& Energy Systems. 33, (2011), pp. 868-874. DOI: 10.1016/j.jijepes.2010.12.017

[11] Hemamalini, S.; Simon, S. P. Dynamic economic dispatch using artificial bee colony algorithm for units with valvepoint effect. // European Transaction on Electrical Power. 21, 1(2011), pp. 70-81. DOI: 10.1002/etep.413

[12] Pothiya, S.; Ngamroo, I.; Kongprawechnon, W. Ant colony optimisation for economic dispatch problem with nonsmooth cost functions. // International Journal of Electrical Power \& Energy System. 32, (2010), pp. 478-487. DOI: 10.1016/j.jjepes.2009.09.016

[13] Pandit, N.; Tripathi, A.; Tapaswi, S.; Pandit, M. An Improved Bacterial Foraging Algorithm for Combined Static/Dynamic Environmental Economic Dispatch. // Applied Soft Computing. 12, (2012), pp. 3500-3513. DOI: 10.1016/j.asoc.2012.06.011 
[14] EhabElattar E. A hybrid genetic algorithm and bacterial foraging approach for dynamic economic dispatch problem. // Electrical Power and Energy Systems. 69, (2015), pp. 1826. DOI: 10.1016/j.jijepes.2014.12.091

[15] Saber, A.Y. Economic Dispatch Using Particle Swarm Optimization with Bacterial Foraging Effect. // International Journal of Electrical Power \& Energy System. 34, (2011), pp. 38-46. DOI: 10.1016/j.jiepes.2011.09.003

[16] Elaiw, A. M.; Xia, X.; Shehata, A. M. Dynamic Economic Dispatch Using Hybrid DE-SQP for Generating Units with Valve-Point Effects. // Mathematical Problems in Engineering. 2012, Article ID 184986 (2014), 10 pages.

[17] Mohammadi-ivatloo, B.; Rabiee, A.; Ehsan, M. Timevarying acceleration coefficients IPSO for solving dynamic economic dispatch with non-smooth cost function. // Energy Conversation and Management. 56, (2012), pp. 175-183. DOI: 10.1016/j.enconman.2011.12.004

[18] Victoire, T. A. A.; Jeyakumar, A. E. A modified hybrid EPSQP approach for dynamic dispatch with valve-point effect. // International Journal of Electrical Power and Energy Systems. 27, 8(2005), pp. 594-601. DOI: 10.1016/j.jijepes.2005.06.006

[19] Passino, K. M. Biomimicry of bacterial foraging for distributed optimization and control. // IEEE Control Systems Magazine. 22, 3(2002), pp. 52-67. DOl: 10.1109/MCS.2002.1004010

[20] Swift, S.; Downie, A. J.; Whitehead, N. A.; Barnard, A. M. L.; Salmond, G. P. C.; Williams, P. Quorum sensing as a population-density dependent determinant of bacterial physiology. // Advances in microbial physiology. 45, (2001), pp. 199-270. DOI: 10.1016/S0065-2911(01)45005-3

[21] Passino, K. M. Bacterial foraging optimization. // International Journal of Swarm Intelligence Research. 1, (2010), pp. 1-16. DOI: 10.4018/jsir.2010010101

[22] Vijay, R. Intelligent bacterial foraging optimization technique to economic load dispatch problem. // International Journal of Soft Computing and Engineering. 2, (2012), pp. 55-59.

[23] Niu, B.; Wang, H.; Duan, Q.; Li, L. Biomimicry of quorum sensing using bacterial lifecycle model. // BMC bioinformatics. S8, (2013), pp. 14. DOI: 10.1186/1471-210514-s8-s8

[24] Panigrahi, C. K.; Chattopadhyay, P. K.; Chakrabarti, R. N.; Basu, M. Simulated annealing technique for dynamic economic dispatch. // Electrical Power Components and System. 34, (2006), pp. 577-586. DOl: $10.1080 / 15325000500360843$

\section{Authors' addresses}

Raviprabakaran Vijay, Assistant Professor

Anna University, Regional Campus,

641046 Coimbatore, India

E-mail: vijai.mtp@gmail.com

\section{Subramanian Ravichandran, Professor \& Dean}

Sri Ramakrishna Engineering College,

641022 Coimbatore, India

E-mail: eniyanravi@gmail.com 